\title{
Effectiveness of Jigsaw-Flash Learning Model in Geometry Material
}

\author{
Imam Pakhrurrozi, Imam Sujadi, and Ikrar Pramudya \\ Magister Pendidikan Matematika, Fakultas Keguruan dan Ilmu Pendidikan, Universitas Sebelas \\ Maret, Jl. Ir. Sutami No. 36A, Surakarta 57126, Indonesia \\ E-mail: imamfahri123@gmail.com
}

\begin{abstract}
This study aims to determine and describe the effectiveness of the use of jigsaw-flash learning model on geometry material. The jigsaw-flash learning model is a jigsaw learning model which is modified with adobe flash media. The research method used is mix method research with exploratory sequential strategy. This research was conducted in state junior high schools in Surakarta. Subjects in this study were the students of class VIII namely class VIII-2 as an experimental class and class VIII-3 as a control class selected by random sampling technique. The experimental class was taught with a jigsaw-flash learning model and the control class was taught with a jigsaw model. The procedures performed in this study include qualitative data collection and data analysis followed by quantitative data collection and data analysis. The researcher used interview method for collecting qualitative data. While quantitative data collection was conducted by test and the analysis technique used was $t$-test. The results of this study indicate that students feel more comfortable and interested in studying geometry material taught by jigsaw-flash model. In addition, students taught using the jigsaw-flash model are more active and motivated than the students who were taught using jigsaw models in studying geometric material. This shows that the use of the jigsaw-flash model can increase student participation and motivation. The results of this study also indicate that the increase in student achievement taught by the jigsaw-flash model which is indicated by $t$-test result $\mathrm{t}=2,259$ with $\mathrm{df}=38$. Based on the results, it can be concluded that jigsaw-flash model is more effective than jigsaw model. Therefore, teachers need to consider the use of jigsaw-flash learning model in learning geometry material.
\end{abstract}

\section{Introduction}

Geometry a branch of mathematics is also objects that we might find in daily life as almost of visual objects around students are part of geometry. It affirms the geometry is paramount subject on learning process for student. Usiskin explained the reason of geometry should be taught to learner [1]. First, geometry is the only field of mathematics that can relate mathematics to the physical form of the real world. Second, geometry, one of the only field, enables ideas of mathematics that can be visualized. The last, it can provide non-single example of mathematics system.

One of geometry purposes on learning process mentioned by Babango is to create students for being a good problem solver [2]. Besides, nowdays geometry is difficult subject to understand and mostly of students object to learn it. To support that opinion, Adolphus explained mathematics subject that is assumed difficult and feared by 
students is geometry [3]. Therefore, it caused students lack of intention to learn it, and the goal of learning for developing problem solver ability cannot be reached.

Based on research of Programme for International Student Assesment 2015, Indonesia ranked 63rd of 70 participants related to math problem solving skills [4]. More than $60 \%$ students in Indonesia are only able to solve math problems in the first level. Moreover, by the report of Trends in International Mathematics and Science Study (TIMSS) 2011, the percentage of student who has correct answer on geometry content is $24 \%$. It shows that the lack of student's skill about geometry [5].

On the other hand, the lack of student ability can be referred on the national exam and intention of student from 2015 to 2016 was decreasing. Based on report of national exam in junior high school level, the average value national exam on mathematics subject in 2015 is 56,28 and 50,24 in 2016 [6][7]. The decreasing of average result of national exam is not apart from the decreasing ability of student to absorb certain material. One of them is the absorption of student in understanding character and element of polyhedra from $51,37 \%$ in 2015 to $47,19 \%$ in 2016 . This result depicts that many of students having problem on fixing question-related to geometry, polyhedra in particular.

Some factors causing the lower achievement and the absorption of student are learning model applicated by teacher has not been effective and student's skills in understanding and memorizing are weak academically[8]. This case is similar as the result of observation by researcher at one of the schools in Surakarta. There are some results of observation that researcher did on learning process. First, fewer students who could answer the question which was asked by teacher. In fact, the material has been delivered in the first meeting. Second, student could not fix different question with the example that has been written by teacher, however, the question is of the same type and difficulty. The last, teacher preferred to use direct learning model and did not maximize the use of learning media on learning process [9].

Based on that case, there are several ways to solve those problems. One of them is the use of learning model that is appropriate in addition to direct learning. On this learning process, student not only becomes a listener, but also student discusses to solve the problem. In this case, cooperative is an appropriate model that should be applied.

Cooperative learning teaches student to work in team, learn to be a responsible person and respect the opinion in each other. This is in accordance with the statement of Johnson and Holubec that "Cooperative learning yields increased efforts among students, more positive interpersonal relationships, and improved mental health when compared to purely individualistic learning" [10]. Cooperative learning increases efforts among student, interpersonal relation which is more positive and mental health improves when compared with individualistic learning. The involvement of students on learning process is expected to improve learning achievement. That was been appropriate with research result by Parveen and Batool that student's learning achievement with cooperative model is more qualified than student's achievement learning with direct model [11]. 
In addition, cooperative learning model that can be applied to apply polyhedra is Jigsaw. Cooperative learning model as Jigsaw was chosen as it assumed that can be used to teach that material. The topic can be divided into four independent sub-items. It means, in each sub-item will not be a prerequisite to others[12]. Therefore, by cooperative learning model is expected more meaningful to increase student understanding.

Besides, Chu argued that "Jigsaw learning method breaks away from the traditional structure based on memorization. It introduces students to the logic of scientific research, as well as developing their capacity for continuing learning" [13]. Jigsaw learning model is not as similar as traditional model that was stressing on memorizing. The type of Jigsaw cooperative learning model provides an opportunity for student to maximize the activity in individual even in a team to identify problem and discuss for using ability that they have

Due to that reaction, It might be for student to understand the material stronger. It is appropriate with Dale's Cone of Experience theory who argued that student only affords to memorize $50 \%$ of material that they were learned by only listen and catch. However, if student active to speak could be afford to remember $70 \%$ of material learned [14]. As the result, the use of Jigsaw learning model is one of alternative to encourage the ability of student to understand the material of polyhedra.

On the other hand, Mbacho explained that the application of Jigsaw learning model can improve the ability of communication and student's achievement [15]. It refers that Jigsaw learning model can be an alternative to encourage student achievement in mathematics learning.

Moreover, there are some weaknesses in this model. One of them is on learning process appeared the discrepancy between student who has high ability and student who has low ability. A student with high ability will be fast response to fix the problem rather than student who is lack of ability on learning [16]. To decrease that discrepancy, we need modification on this learning model as using a media.

Learning media can be used for alternative solution to decrease discrepancy between student with high ability and low ability [17]. The use of learning media on mathematic is very worthwhile, considering the concept is abstract, especially for student whose development stage is still in concrete operational phase. Therefore, the type of cooperative Jigsaw learning model needs to help by using media.

In reality, learning media has not been used by all teachers. By this media on learning process can improve the intention and student's achievement. This is in accordance with reserch result of Supardi who defined that learning media can encourage the intention and student's achievement [18]. Even though there are tutors who applied this media on learning process of polyhedra. On the other hand, the learning media tends to be a concrete object (props). The media is considered less effective and efficient in providing information, based on the current of technology development. 
Many software can actually be used to help on mathematics learning, one of them is software adobe flash. Adobe Flash is a software of computer used to create vector and animation. Besides, Adobe flash can use programming code which is worked by itself to arrange animation on it. By Adobe flash features can be made an interactive audio visual learning media and interesting for learning mathematics. By this media, student can view the image and presentation of the material clearly and meaningfully related to polyhedra.

\section{Method}

The method of this research used mix method research with sequential exploratory strategy. Mix method explained by Hesse-Biber is research method integrating the quantitative method and qualitative method which are including data collection, data analysis and data merging of quantitative and qualitative data to answer the problem on the research [19]. The sequential exploratory design depicted by Cresswel is combination process and qualitative data analysis at the first stage, whereupon followed by the collection and analysis data quantitative at the second stage based on the results at the first stage [19].

Data retrieval and qualitative analysis are the first procedure on research, qualitative data collection taken by observation method and interview. Qualitative data analysis techniques used analysis explained by Miles and Huberman including data reduction, data display, and data verification [20]. Furthermore, the second procedure on this research is data retrieval and quantitative analysis. Quantitative data retrieval used achievement test and t-test is the data analysis technique used in this research.

This research was held in junior high school 3 Surakarta at VIII grade and sampling technique used is random technique sampling. Furthermore, it has been chosen by two classes such as class of VIII-2 to be experiment class and class of VIII-3 to be control class with each class of 20 students. The experiment class was taught by jigsaw-flash model and the control class was taught by jigsaw model.

\section{Result and Discussion}

As outlined at the beginning, the results and discussions will divided into two parts. First analysis is Qualitative analysis and the second is quantitative analysis.

\subsection{Qualitative Analysis}

Based on the result of interview, the subject of experiment class gave a positive response of applying the jigsaw-flash method. The students were more active on discussion and thought getting help to understand geometry with flash media. It was different from control class who is taught by regular jigsaw method, where the response of control class mentioned that the learning model applied has not many differences as usual. The students were less interested on learning process, however, only a few of students excited on this learning. 
Furthermore the subjects of experiment class conveyed that the process of jigsawflash learning model increasing motivation of curiosity about geometry due to supported by interesting media. The subjects in experimental class also mentioned that the process of jigsaw-flash learning model created the process of learning more enjoyable and not too addicted of book. Besides, there is something which is interesting that can attract the intention of students. Different from the subject of control class by the jigsaw learning model delivered that motivation of student's curiosity only on several students who like mathematics, while few of student felt getting less motivation so that on learning process students have not good intention to join the class.

The opinion of experiment class mentioned that the learning process is more interesting and enjoyable as students learnt by interesting and interactive media. The learning is more meaningful due student can see visually the object of geometry. In addition, on this learning, students can be trained for having the ability to think and build the sense of social as in team work, and can give an appreciation to other students. Enthusiasm of student when applying the adobe flash media can be seen on discussion process and delivering the material of group. Students participated actively in discussion process.

According to teacher application model of jigsaw-flash argued that it is more effective than regular jigsaw. The subjects of experiment class are easier to understand the material. For the experiment class, one sub-material can be completed in one meeting. Therefore, it can be expected that the jigsaw-flash learning model is more effective than jigsaw. On the other hand, it can be seen theoretically the benefit of jigsaw-flash model in comparing with regular jigsaw model. Based on the first description, Jigsaw-flash model is a modification of jigsaw learning model, which distinguishes it is on expert sheet. On jigsaw model, the expert sheet which is given is paper. While on jigsaw-flash model, the expert sheet is audio visual media of adobe flash software. Media in this study, researchers developed their own adobe flash media used, developed by adjusting the learning model. The expert sheet can be seen in the figures below which is used by each learning model.

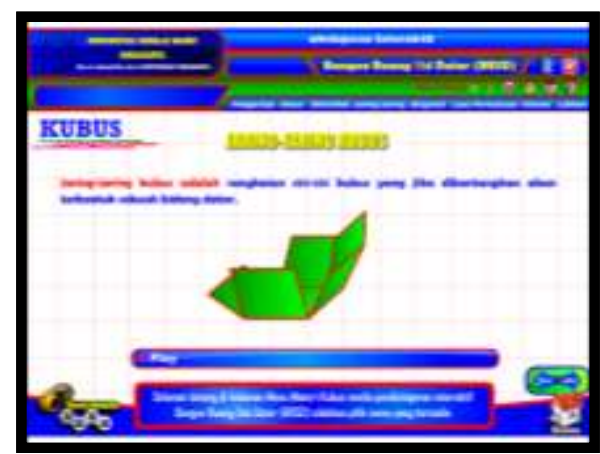

Figure 1 (adobe flash media for Jigsaw-flash) ordinary Jigsaw)

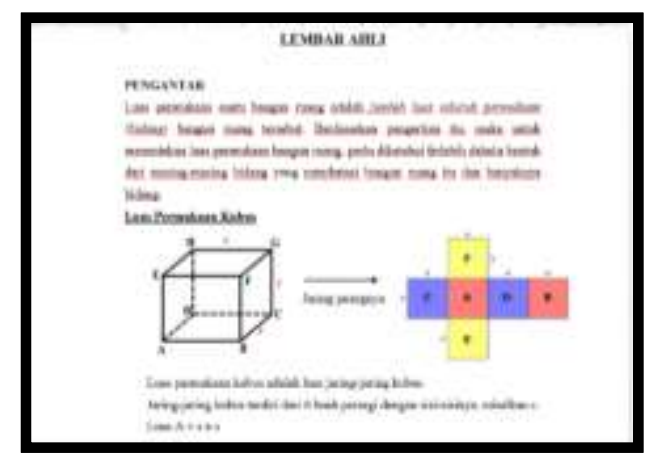

Figure 2 (Expert sheet for

Both of images above shows clearly the difference of expert sheet used. Adobe flash media (Figure 1) is more interesting to attract the intention of student and students can 
see the visual form of cube webs. This becomes a significant difference on (Figure 2) which depicted illustration of cube webs that is common for student which made it less attractive. Benefit and efficiency are the added value of the jigsaw-flash learning model, based on description of Sudjana includes the benefit of learning media [18]. These benefits are children's learning materials have more clear meaning so that can be understood by students and may reach the purposes of learning. On this research, adobe flash media which is used on jigsaw learning model is expected to be beneficial for providing students on understanding of geometry.

\subsection{Quantitative Analysis}

Based on the results of analysis the study obtained hypothesis to be used in the quantitative analysis. In this research using t-test. Before it, the sample have to test the normality distribution and data having same variance. In this case use software SPSS 16.

\section{Normality test}

Normally test used to find out whether the data of samples from population is normally distributed. In this research, normally test by Shapiro-Wilk. Here is the result of normally test with significance level of $5 \%$.

Table 1. The Result of Normality Test of Mathematics Achievement

\begin{tabular}{llll}
\hline Kelas & Static & df & Sig. \\
\hline Jigsaw-Flash (eksperimen) & 0,951 & 20 & 0,384 \\
Jigsaw ( Kontrol) & 0,968 & 20 & 0,710 \\
\hline
\end{tabular}

Based on table 1, see that significancy for each samples more than 0,05 (alpha). So that, Samples were taken from normally distributed populations.

\section{Homogeneity Test}

Homogeneity test to find out whether the data of population have same variance or not. In testing this homogeneity by Levene's statistic method. The result of homogeneity test with significance level of $5 \%$ as follows.

Table 2. The Result of Homogeneity Test of Mathematics Achievement

\begin{tabular}{llll}
\hline Levene Statistic & df1 & df2 & Sig. \\
\hline 0,132 & 1 & 38 & 0,718 \\
\hline
\end{tabular}

Based on table 2, Sig. value is 0,718 more than 0,05 (alpha). So that, variant of two groups sample data is the same.

\section{t-Test}

After test of normality and homogenity, the researcher conducted t-test for testing the hyphotesis. The result of t-test is son in the table 3. 
Table 3. The result of t-test

\begin{tabular}{|c|c|c|c|c|c|}
\hline & \multicolumn{2}{|c|}{$\begin{array}{c}\text { Levene Test for Equality } \\
\text { of Variances }\end{array}$} & \multicolumn{3}{|c|}{ t-test for equality of means } \\
\hline & $\mathrm{F}$ & Sig. & $\mathrm{t}$ & $\mathrm{df}$ & Sig. (2-tailed) \\
\hline $\begin{array}{l}\text { Equal variances } \\
\text { assumed }\end{array}$ & 0,132 & 0,718 & 2,259 & 38 & 0,03 \\
\hline $\begin{array}{l}\text { Equal variances not } \\
\text { assumed }\end{array}$ & & & 2,259 & 37,745 & 0,03 \\
\hline
\end{tabular}

Based tabe 3, the final result of the research is $t=2,259$ with $\mathrm{df}=38$ and $\mathrm{t}(0.95)$ $(38)=2.02$. The test criterion is $t_{\text {count }}$ compared with $t$ table with significant level $\alpha=$ $5 \%$ with df $=n 1+n 2-2$, if $t_{\text {count }}>t_{\text {table, }}$, then $H_{0}$ is rejected and $\mathrm{H}_{\mathrm{a}}$ accepted. The calculation results show that $\mathrm{H}_{\mathrm{a}}$ is accepted, that meaning the average value of the experimental group is higher than the average value of the control class. Based on this it can be concluded that jigsaw-flash model is more effective than ordinary jigsaw model. Therefore, teachers need to consider the use of jigsaw-flash learning model in learning geometry material.

Conclusion

Based on the results and discussion jigsaw-flash learning can increase motivation and curiosity of students on geometry learning. Jigsaw-flash learning can also create the process on learning more interesting, enjoyable, and meaningful. In addition, the model of jigsaw-flash learning which used flash media can help teacher to explain the concept of geometry abstract form to be more concrete. The result of this data is valid based on t-test which depicted the value of average experiment group (Jigsaw-flash) is higher than the value of control class (jigsaw). In conclusion, the data of jigsaw flash learning model is more effective than regular jigsaw.

Therefore, Jigsaw-flash learning model is expected to be used by teacher on mathematics learning process, geometry in particular. Besides, it can be improved and continued a research about application of media on learning process to create mathematics more preferable, practice and efficient.

\section{References}

[1] Usiskin Z 1982 Van Hiele Levels and Achievement in Secondary School Geometry. (Final report of the Cognitive Development and Achievement in Secondary School Geometry Project.) Chicago: University of Chicago. ERIC Document Reproduction Service No. ED220288

[2] Abdussakir 2010 Pembelajaran Geometri sesuai Teori Van Hiele El-Hikmah Jurnal Kependidikan dan Keagamaan p 1693-1499.

[3] Adolphus T 2011 International Journal of Emerging Sciences 1 143-152.

[4] Programme for International student Assesment PISA 2016 Results Excellence and Equity in Education Volume I (Paris: OECD Publishing)

[5] Mullis I, Martin M, Foy P, and Arora A 2012 TIMMS 2011 International Result in Mathematics Chestnut Hill: TIMSS \& PIRLS International Study Center. 
[6] BSNP (2015) National Exam Report in 2015

[7] BSNP (2016) National Exam Report in 2016

[8] Rowe K 2006 Australian Council for Education Research 104

[9] Liza C 2015 Delta Journal of education 5 10-19

[10] Attle S and Parker B 2007 International Journal of Teaching and Learning in Higher Education. 19 77-83

[11] Parveen Q and Batool 2012 International Education Studies 5 154-158

[12] Ataman K 2017 Universal Journal of education Research 5 420-434

[13] Chu S 2014 Aplication of the Jigsaw Cooperatif Learning Method in Economic Course. International Journal of Managerial Studies and Research 10 166-172

[14] Jacobs G, Hurley M, \& Unite, C. 2008 How Learning Theory Creates a Foundation for SI Leader Training. Journal of Peer Learning 1 6-12.

[15] Mbacho W and Bernard N G 2014 Effects of Jigsaw Cooperative Learning Strategy on Students' Achievement in Secondary School Mathematics in Laikipia East District Asian Journal of Management Sciences and Education 2 177-188

[16] Ljubica K 2013 The Journal of Teaching English for Specific and Academic Purposes 1 53-58

[17] Signe S and Rikke O 2015 The elelctronic Journal of e-Learning 13 278-290

[18] Supardi 2010 Effect of Learning Media and Learning Interest on Physics Learning Result Journal formatif 2 71-81

[19] John W. Creswell 2014 Research Design Qualitative, Quantitative, and Mixed Methods Approaches-SAGE Publications, (London: SAGE Publications) pp 285-287

[20] Sugiyono 2013 Metode penelitian pendidikan (Bandung Alfabeta) p 337 